\title{
Skill retention after school-leaving: Analysis of data from the Malawi Schooling and Adolescent Study
}

Erica Soler-Hampejsek

Barbara Mensch

Population Council

Stephanie Psaki

Population Council

Monica J. Grant

Christine A. Kelly

See next page for additional authors

Follow this and additional works at: https://knowledgecommons.popcouncil.org/departments_sbsr-pgy

Part of the Demography, Population, and Ecology Commons, Family, Life Course, and Society Commons, Gender and Sexuality Commons, and the International Public Health Commons How does access to this work benefit you? Let us know!

\section{Recommended Citation}

Soler-Hampejsek, Erica, Barbara Mensch, Stephanie Psaki, Monica J. Grant, Christine A. Kelly, and Paul C. Hewett. 2018. "Skill retention after school-leaving: Analysis of data from the Malawi Schooling and Adolescent Study," research brief. New York: Population Council. 


\section{Authors}

Erica Soler-Hampejsek, Barbara Mensch, Stephanie Psaki, Monica J. Grant, Christine A. Kelly, and Paul C. Hewett 


\section{SKILL RETENTION AFTER SCHOOL-LEAVING}

ANALYSIS OF DATA FROM THE MALAWI SCHOOLING AND ADOLESCENT STUDY

\section{The extent to which skills acquired during schooling are retained after school-leaving in developing countries remains largely unknown.}

This brief describes findings from an analysis of a longitudinal dataset of Malawian adolescents aged 14-17 attending school when first interviewed in 2007. We investigate whether literacy and numeracy skills at school-leaving-among those who dropped out before completing secondary school-were retained several years after.

We find a significant gender difference in skill level after school-leaving for English skills, even after controlling for initial skill level and grade attainment, with females scoring lower than males. Although the gender difference in numeracy is not significant, females score lower than males after schoolleaving.

\section{Key findings}

- English oral reading and numeracy skills deteriorated and reading comprehension skills in the local language and English improved after school-leaving.

- Females score significantly lower than males on English oral reading and comprehension skills after school-leaving. Females had 36\% lower odds of being able to read than their male counterparts and a 0.42 lower average on reading comprehension out of a possible score of 5 .

- While females are less likely to read, listen to radio, and watch television, these variables do not explain gender differences in skills after school-leaving.

- Grade attainment is the critical factor explaining variability in skill level after school-leaving.
The skills young people develop in school provide an essential foundation that can either be reinforced or deteriorate depending on the strength of the foundation and opportunities after leaving school. FULL STUDY GOALS, METHODOLOGY,
AND FINDINGS:

Soler-Hampejsek, E., B.S. Mensch, S.R. Psaki, M.J. Grant, C.A. Kelly, and P.C. Hewett. 2018. "Reading and numeracy skills after school leaving in southern Malawi: A longitudinal analysis," International Journal of Educational Development 59 (March): 86-99. 
The Malawi Schooling and Adolescent Study (MSAS)

MSAS is a longitudinal survey that followed 2,649 adolescents, both in primary school and out of school who were aged 14-17 when first interviewed, over a six-year period from 2007-13.

The survey was conducted in two predominantly rural southern districts of Malawi, Balaka and Machinga, and included an extensive set of questions on household and family characteristics, educational attainment, schooling history and experiences, household labor and employment, sexual behavior, marriage, and health.

The study also included short assessments of oral reading and reading comprehension in English and Chichewa, the two official languages, and written numeracy skills.

This present study uses data from those adolescents $(n=1,118)$ who were attending school in 2007 but were known to have left school during the course of MSAS for whom we have an assessment of skills close to the time of school-leaving as well as at least one subsequent assessment of skills.

For more information:

http://www.popcouncil.org/research/ malawi-schooling-and-adolescent-study

\section{Background}

Over the past few decades, considerable attention has been placed, and progress made, on increasing access to schooling and narrowing the gender gap in primary school enrollment in developing countries (Lloyd and Hewett 2009). In recent years, focus has been shifting from expanding access to improving learning outcomes (UNESCO 2005 and 2006; van der Gaag and Adams 2010; Perlman Robinson 2011). Several studies have documented the low levels of learning among students in developing countries (Hungi et al. 2010; Pritchett 2013; Spaull and Taylor 2015).

Data suggest that math, science, and reading skills-as distinct from years of schooling-yield strong economic returns, both at the individual level and as a driver of growth (Hanushek and Woessman 2008). In addition, adult literacy, particularly for females, has been linked to improved maternal and child health (Smith-Greenaway 2013a and 2013b), increased political engagement (Burchfield et al. 2002), and greater likelihood of sending children to school (Abadzi 2003).

Although literacy and numeracy can be developed outside the classroom, formal education represents the primary means for acquiring such skills. It is important to ensure, particularly in view of the resources devoted to supporting global education systems, that students acquire foundational skills while in school, and can retain those skills upon school-leaving.

Policymakers, education practitioners, and researchers should not assume that students' academic skills on the day they leave formal schooling will last throughout their lives. In designing effective education interventions, it is important to identify the factors that influence skill acquisition and support skill retention.

Our findings emphasize that the skills young people develop in school provide an essential foundation that can either be reinforced or deteriorate depending on the strength of the foundation and opportunities after leaving school. 


\section{The Malawian context}

Studying the retention of skills is particularly relevant in an environment such as Malawi.

In 1994, the country became one of the first in sub-Saharan Africa to introduce free primary education.

This policy change resulted in large increases in enrollment, but these were not accompanied by corresponding investments in school quality (Kendall 2007). Access to the first grade of primary school is almost universal, but the rate of dropout remains very high thereafter. Due both to the large fraction who drop out before completing a level and very high repetition rates, the World Bank estimates that it takes 23 student years to produce one Standard 8 graduate (World Bank 2010).

Complicating the process of skills acquisition is the multilingual structure of Malawi's education system. At the time of data collection, the first four standards of primary school were taught in the dominant language of a particular school's catchment area, and English was the official language of instruction beginning in Standard 5. English was then, and still is, taught as a subject in all primary standards. Proficiency in English is currently required for entry into secondary school as it was during the time of data collection.

\section{Methodology}

Literacy Assessment: For the oral assessment, respondents were asked to read aloud two sentences in Chichewa and two sentences in English. The reading of each sentence was scored by the interviewer as:

a) cannot read any part of the sentence, b) able to read only part, and c) able to read the whole sentence. Starting in round 2 (2008), reading comprehension assessments in Chichewa and English were also conducted. For each language, respondents were given one minute to read a short passage out loud; the Chichewa passage had 73 words and the English passage had 86 words. Those who read at least the first 26 words (first three sentences) in Chichewa were then asked six questions about the content, and those who read at least the first 35 words (first three sentences) in English were asked five questions.

Different passages and questions, but of similar length and complexity, were used in rounds 3 (2009) and 5 (2011), while the round 2 passages and questions were repeated in rounds 4 (2010) and 6 (2013). Scores ranged from 0-6 for reading comprehension in Chichewa, and 0-5 for reading comprehension in English, according to the number of questions answered correctly. If the respondent could not read at all, or could not read the first three sentences within one minute, or read the first three sentences but did not correctly answer any of the questions, he/she was given a score of zero.
Numeracy Assessment: At round 1 (2007), the numeracy assessment consisted of 12 questions drawn from achievement tests for Standard 3 developed by the Malawi Institute of Education, a para-statal charged by the Ministry of Education with student assessment. The numeracy questions used included sequencing and ordering numbers, addition, subtraction, multiplication, division, and two word problems involving simple monetary transactions. Respondents were given unlimited time to complete the numeracy assessment. A similar assessment, but with questions involving different numbers, was used in round 2 and repeated in rounds 4 and 6 . The round 1 numeracy assessment was repeated in rounds 3 and 5. The numeracy score is the total number of correct answers to the 12 problems in the assessment.

We investigated Chichewa and English reading ability and reading comprehension, and numeracy, after school-leaving for males and females. The study incorporated information on other factors potentially related to skill level after school-leaving including skill level at school-leaving, parental education, grade attainment, age at school-leaving, labor force participation, marital and childbearing status, whether the household had any books or a cell phone, and opportunities to apply skills after leaving school including reading, listening to the radio, or watching television. 


\section{Findings}

Chichewa oral reading skills did not change significantly over time for males or females; more than $90 \%$ of respondents were able to read both sentences each time they were assessed.

In contrast, Chichewa reading comprehension skills increased between schoolleaving and the last assessment, both for males (9\% increase) and females (7\% increase).

A different pattern was observed for English literacy skills. For both males and females separately, a significant decline was observed in English oral reading skills between school-leaving and the final assessment. Whereas $76 \%$ of both male and female respondents were able to read English sentences aloud at school-leaving, by the last assessment this proportion had declined significantly to $70 \%$ for males and $64 \%$ for females.

As with Chichewa, English comprehension skills increased significantly for both males and females between the initial and final assessments; the average scores increased $24 \%$ among females and $19 \%$ among males.

While fewer adolescents are able to read after school-leaving in comparison to around the time of school-leaving, those who can read understand more of what they are reading.

\section{Ability to read aloud and reading comprehension in English: MSAS respondents in school at baseline}

Percent able to read aloud in English $100 \%$

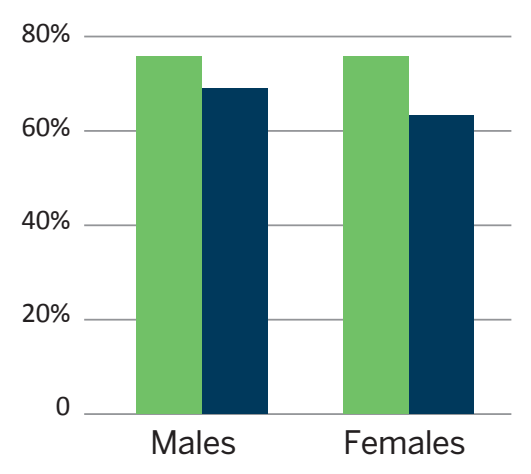

Around school-leaving
Mean number of correct answers to 5 reading comprehension questions in English

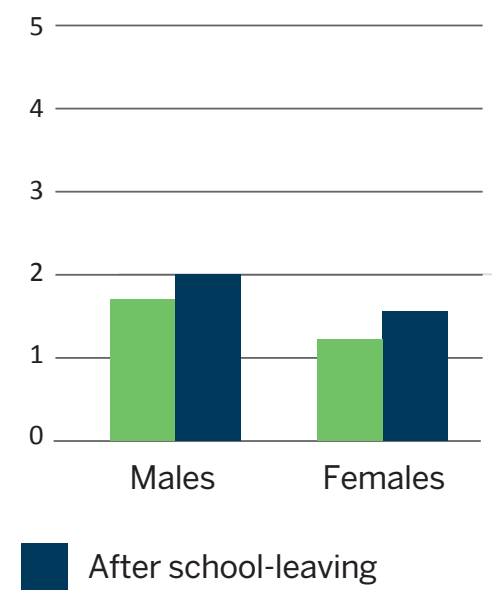


Numeracy skills declined significantly for both males and females between school-leaving and the last assessments. Overall, the average numeracy score dropped by $11 \%$ among females and $5 \%$ among males.

Numeracy score: MSAS respondents in school at baseline

Mean number of correct answers to 12 numeracy questions 12

10

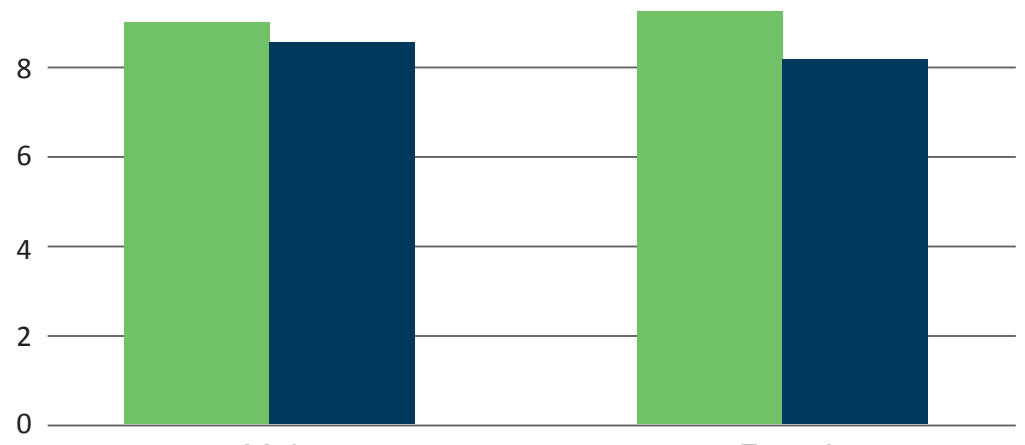
Males

Females

Around school-leaving

After school-leaving

Change in skills between assessment around school-leaving and last assessment after school-leaving

\begin{tabular}{|lll|}
\hline & Males & Females \\
\hline Chichewa oral reading & loss & loss \\
\hline Chichewa reading comprehension & gain*** & gain*** \\
\hline English oral reading & loss $^{*}$ & loss $^{* *}$ \\
\hline English reading comprehension & gain $^{* *}$ & gain $^{* *}$ \\
\hline Numeracy & loss $^{* *}$ & loss $^{* *}$ \\
\hline
\end{tabular}

Difference between assessment near and after school-leaving significant at: ${ }^{*} p<0.05,{ }^{* *} p<0.001$. 
The descriptive results raise several questions, which we address in multivariate analyses:

\section{Is there a gender difference in skill level?}

A significant gender difference in skill level is observed after school-leaving for English oral reading and reading comprehension skills, even after controlling for initial skill level and grade attainment, with females scoring lower than males.

Females had approximately $40 \%$ lower odds of being literate than their male counterparts and had a $42 \%$ lower average on reading comprehension.

While the gender differences in numeracy and in Chichewa oral reading and reading comprehension are not statistically significant, it is worth noting that the mean Chichewa reading and numeracy scores were consistently lower for females than for males after school-leaving.

\section{Is the gender difference due to differential opportunity to apply skills?}

Females were significantly and substantially less likely than males to read, listen to the radio, and watch television after school-leaving. For example, $51 \%$ of males compared to $31 \%$ of females reported reading something in the week prior to the round 6 survey in 2013.

Young women were considerably more likely to be married and have children by round 6 than young men who presumably were more likely to frequent venues where there were newspapers, television, and radio.

This differential exposure, however, does not appear to explain the gender gap in English oral reading and reading comprehension, as the association between gender and reading skills changed little after the addition of these variables to the statistical models.

\section{Which characteristics affect skill level after school-leaving?}

As expected, those who had attended secondary school had a significantly higher skill level for all outcomes.

Age at school-leaving was negatively and significantly associated with skill level after school-leaving for all outcomes except English reading comprehension; the older the respondent when leaving school-which after controlling for grade attainment primarily reflects the effect of grade repetition, late entry, and temporary withdrawals - the lower the subsequent skill level.

Also, as expected, skill level after school-leaving was positively and significantly associated with skill level at school-leaving for all outcomes.

No other demographic or socioeconomic variable was consistently associated with skill level in multivariate analyses. 


\section{Conclusions and programmatic implications}

Our analyses indicate that grade attainment is the critical factor explaining variability in skill level after school-leaving. Future intervention research should identify those factors that determine grade progression and completion, which our research has identified as the key factors promoting skill retention after school-leaving.

That those with lower grade attainment have inferior skills after school-leaving suggests that students who remained in school longer were more likely to apply and reinforce their skills after leaving school, whereas those who left school earlier, particularly females, may not have had the same opportunities. This difference in the opportunity to apply skills after leaving school may reflect a different value placed on education, especially for girls.

These findings have important implications for education policy and programs.

Expectations about the potential demographic and public health benefits of education, particularly the education of women, are based on an assumption that these relationships will remain consistent across generations of school-goers.

\section{Education practitioners and researchers} should not assume that students' academic skills on the day they leave formal schooling will last throughout their lives.

Rather, our findings demonstrate that the skills young people develop in school can either be reinforced or deteriorate depending on the strength of the foundation, and opportunities after leaving school.

\section{References}

Abadzi, Helen. 2003. "Adult Literacy: A Review of Implementation Experience." Washington, DC: World Bank, Operations Evaluations Department

Burchfield, Shirley et al. 2002. "A Longitudinal Study of the Effect of Integrated Literacy and Basic Education Programs on Women's Participation in Social and Economic Development in Nepal." Girls' and Women's Education Policy Research Activity. Washington, DC: USAID.

Hanushek, Eric A. and Ludger Woessman. 2008. "The role of cognitive skills in economic development," Journal of Economic Literature 46(3): 607-668.

Hungi, N. et al. 2010. "SACMEQ III Project Results: Pupil Achievement Levels in Reading and Mathematics." Southern and Eastern Africa Consortium for Monitoring Educational Quality, Harare.

Kendall, Nancy. 2007. "Education for all meets political democratization: Free primary education and the neoliberalization of the Malawian school and state," Comparative Education Review 51(3): 281-305.

Lloyd, Cynthia B. and Paul C. Hewett. 2009. "Educational inequalities in the midst of persistent poverty: Diversity across Africa in educational outcomes," Journal of International Development 21(8): 1137-1151.

Perlman Robinson, Jenny. 2011. "A Global Compact on Learning: Taking Action on Education in Developing Countries." Washington, DC: Center for Universal Education at Brookings.

Pritchett, Lant. 2013. "The Rebirth of Education: Schooling Ain't Learning." Washington, DC: Center for Global Development.

Smith-Greenaway, Emily. 2013a. “Mothers' reading skills and child survival in Nigeria: Examining the relevance of mothers' decision-making power," Social Science \& Medicine 97: 152-160.

. 2013b. "Maternal reading skills and child mortality in Nigeria: A reassessment of why education matters," Demography 50(5): 1551-1561. 
Spaull, Nicholas and Stephen Taylor. 2015. "Access to what? Creating a composite measure of educational quantity and educational quality for 11 African countries," Comparative Education Review 59(1):

133-165.

UNESCO. 2005. "EFA Global Monitoring Report 2005:

Education for All-The Quality Imperative." Paris:

UNESCO.

2006. "EFA Global Monitoring Report 2006:

Education for All-Literacy for Life." Paris: UNESCO.

van der Gaag, Jacques and Anda Adams. 2010. "Where

Is the Learning? Measuring Schooling Efforts in

Developing Countries." Washington, DC: The Brookings

Institution.

World Bank. 2010. "The Education System in Malawi."

World Bank Working Paper No. 182. Washington, DC:

World Bank.

Research reported in this brief was supported by the Eunice Kennedy Shriver National Institute of Child Health and Human Development of the National Institutes of Health under Award Numbers R01HD047764 and R01HD062155, the William and Flora Hewlett Foundation, the John D. and Catherine T. MacArthur Foundation, and the Spencer Foundation.

Suggested citation: Soler-Hampejsek, E., B.S. Mensch, S.R. Psaki, M.J. Grant, C.A. Kelly, and P.C. Hewett. 2018. "Skill Retention after School-Leaving: Analysis of Data from the Malawi Schooling and Adolescent Study." Research Brief. New York: Population Council.

(c) 2018 The Population Council, Inc. 